\title{
Correction to: Decisional authority of gamete donors over embryos created with their gametes
}

\section{Guido Pennings ${ }^{1}$}

Published online: 15 February 2020

(C) Springer Science+Business Media, LLC, part of Springer Nature 2020

\section{Correction to: Journal of Assisted Reproduction and Genetics} https://doi.org/10.1007/s10815-019-01678-5

The original article unfortunately contained a mistake. The name of the author should be listed as "Guido Pennings".

The original version has been corrected.

Publisher's note Springer Nature remains neutral with regard to jurisdictional claims in published maps and institutional affiliations.

The online version of the original article can be found at https://doi.org/ 10.1007/s10815-019-01678-5

\section{Guido Pennings}

Guido.Pennings@ugent.be

1 Department of Philosophy and Moral Science, Bioethics Institute Ghent (BIG), Ghent University, Blandijnberg 2,

B-9000 Ghent, Belgium 